\title{
Current Problem of Education Management: Subjective Attitude of University Teachers to Changes in Higher Education
}

\author{
Elena G. Gutsu' ${ }^{1,}$, Nadezda N. Demeneva1, Tatiana V. Mayasova ${ }^{2}$, Oksana V. Kolesova ${ }^{1}$, \\ Elena V. Kochetova', Svetlana K. Tivikova ${ }^{3}$ \\ ${ }^{1}$ Department of Psychology and Pedagogy of Preschool and Primary Education, Minin Nizhny Novgorod State Pedagogical University, \\ Russia \\ ${ }^{2}$ Department of Human Physiology and Safety, Minin Nizhny Novgorod State Pedagogical University, Russia \\ ${ }^{3}$ Department of Primary Education, Nizhny Novgorod Institute of the Education Development, Russia
}

Received July 30, 2020; Revised September 16, 2020; Accepted October 19, 2020

\section{Cite This Paper in the following Citation Styles}

(a): [1] Elena G. Gutsu, Nadezda N. Demeneva, Tatiana V. Mayasova, Oksana V. Kolesova, Elena V. Kochetova, Svetlana K. Tivikova , "Current Problem of Education Management: Subjective Attitude of University Teachers to Changes in Higher Education," Universal Journal of Educational Research, Vol. 8, No. 11B, pp. 6036 - 6041, 2020. DOI: 10.13189/ujer.2020.082239.

(b): Elena G. Gutsu, Nadezda N. Demeneva, Tatiana V. Mayasova, Oksana V. Kolesova, Elena V. Kochetova, Svetlana K. Tivikova (2020). Current Problem of Education Management: Subjective Attitude of University Teachers to Changes in Higher Education. Universal Journal of Educational Research, 8(11B), 6036 - 6041. DOI: 10.13189/ujer.2020.082239.

Copyright $@ 2020$ by authors, all rights reserved. Authors agree that this article remains permanently open access under the terms of the Creative Commons Attribution License 4.0 International License

\begin{abstract}
The beginning of the 2000s has been marked by the processes of large-scale reform of the higher education system in Russia. The implementation of the ideas of modernization has been entrusted to university teachers. The actual results of the announced transformations largely depend on how teachers perceive and treat the ongoing changes. The article considers the subjective attitude of teachers to the following changes in higher education: introduction of competency-based approach in higher education, reduction of classroom time and contact work with students, technologization of the learning process, introduction of performance-based contracts for teachers, and increase in the proportion of remote training (including full-time students). The research results have shown that most of the teachers who took part in the survey, regardless of the length of service in the university, are rather indifferent to the changes in the higher education system. The influence of most changes on the content and specifics of the teachers' work, on the quality of the teachers' work (the quality of the students' preparation), as well as on the professional development is assessed by the survey participants as insignificant. This indicates that most of the changes, according to the
\end{abstract}

subjective opinion of the teachers who took part in the study, do not have significant impact on the real situation in higher education. The obtained empirical data are of interest for psychology, management and management of higher education.

Keywords Competency-based Approach, University Teacher, Changes in the System of Higher Education, Subjective Attitude

\section{Introduction}

The university teacher is the central figure in the reform of the higher education system. The nature and pace of modernization processes largely depend on how innovative ideas will be accepted by those on whom their direct implementation depends, that is, by teachers [1]. The values and goals set in the reforms and normative documentation are refracted through the prism of the value system of a particular teacher [2]. Therefore, the problem of the personality of the teacher as a subject of professional 
pedagogical activity has now been taken as one of the central positions in research [3].

Numerous studies $[4,5]$, including those conducted by the authors [6, 7], have shown that the subjective perception and experience of a specific teacher with the processes occurring in higher education are ambiguous. Not always declared ideas are accepted and become personally significant for a particular teacher. Consequently, the real developing effect of education often does not correspond to the stated idea of modernization. This problem stipulated the choice of the research subject.

This paper aims to study the subjective attitude of teachers in the system of higher education to certain changes and innovative processes taking place in the system of higher education.

This goal is implemented through the following tasks:

1. Identify changes in higher education, which, according to the subjective opinion of teachers, seem to be the most tangible.

2. Reveal the subjective perception of teachers about the impact of changes in higher education on the content and specifics of teachers' work, the quality of teachers' work (the quality of students' training) and on professional development.

3. Determine the dependence of the subjective attitude of teachers to changes in higher education on the length of service at the university.

The authors chose the following changes for analysis: introduction of competency-based approach, reduction of classroom time, technologization of the learning process, introduction of performance-based contracts for teachers, and increase in the proportion of remote training, including full-time students.

The results of the pilot study proposed in this work are important, not so much for the general theory of higher education as for the understanding the real state of affairs in modern higher education.

\section{Literature Review}

Education is, above all, the interaction of individuals. Therefore, the most developing educational resource is not so much the technology and equipment of the educational process as the personality of the teacher. The personal sphere of the teacher is responsible for the value-semantic component of the content of education. If the personality of the teacher is not taken into account, then the most important resource for improving the quality of education is missed [8].

This issue has become particularly pressing in connection with the wide modernization processes taking place in the modern system of higher education. The issues of reforming higher education are widely discussed by both Russian $[9,10]$ and foreign [11-13] researchers. It is not surprising that the personality of the teacher as a subject of the professional pedagogical activity, capable of self-development, has taken one of the central positions in modern research.

Academic literature covers a fairly wide range of issues devoted to the personality of the university teacher: professionally important qualities of the higher education teacher, as well as conditions for their development; value and semantic-based orientation, motivation of professional activity, problems of self-realization and self-actualization; problems of professional deformation and professional crisis of the higher school teacher (T.A. Zhagalina [14], N.O. Sadovnikova and A.M. Mirzaahmedov [15] and others).

In connection with the research issue, the authors would like to highlight works devoted to the study of the specifics of the teachers' activity in modern conditions of innovation (E.F. Zeer and E.T. Konyukhova [16], O.V. Manyakhina [17], E.V. Myalkina [18], I.G. Sevastyanova, V.N. Stegnii and A.G. Sposib [19], I.F. Filchenkova [20], L. Armstrong [21], etc.).

The importance of the subjective attitude of the teacher to professional reality is emphasized. Yu.V. Senko and M.N. Frolovskaya introduce the concept of "professional image of the teacher's world". According to the authors, it includes the values and meanings of education and the style of pedagogical thinking, which are actively involved in the analysis and personal experience of the existing socio-cultural situation, in extracting the pedagogical task from it, in finding ways to implement and solve it, and in analyzing results [22].

In practice, in a particular university and a specific audience, the educational process functions not as an officially defined state project, but rather its subjective modification refracted through the system of values, meanings and relations of a particular teacher. Therefore, an essential point for understanding the real processes in education is the awareness of how the changes occurring in the higher education system are subjectively perceived and experienced by teachers themselves.

The problem of the attitude of teachers towards changes in the system of higher education is widely discussed in academia. Numerous studies draw attention to the negative aspects associated with the personal attitude of teachers to the real situation in the higher education system.

Thus, M.V. Field has analyzed the attitude of the faculty of universities to modern students and teaching technologies of academic disciplines in her study. The paper states that the perception of the professional situation depends on the age of teachers. At the same time, it identifies certain general trends, such as teachers' perception of modern students in a more negative aspect (low motivation, lack of basic knowledge, infantilism, biased self-esteem, etc.) and the need to combine new and classical teaching systems [23].

Of significant interest is the study by P.A. Ambarova, 
G.E. Zborovsky and N.V. Shabrova which analyzes the problem of the crisis of trust in the system of higher education [24]. The authors identified the occurrence of the "anti-confidence" phenomenon among the teaching staff in relation to the educational policy implemented in higher education.

S.B. Seryakova and L.F. Krasinskaya come to similar conclusions in the study which analyzed the attitude of teachers to some changes in higher education. It is noteworthy that, according to the authors, the overwhelming majority of teachers negatively or ambiguously evaluate both the general state of affairs in higher education and certain proposed criteria, for example, attitude to the ongoing reform, the introduction of federal education standards (FESs), the ability to improve the quality of training students by means of ongoing reforms, the introduction of an effective contract for teachers, etc. It is also interesting that the authors revealed that the attitude to various changes depended on teachers' age [25].

Many studies focus on the fact that tight control with the help of administrative resources is not always applicable to the creative nature of the teacher's activities. The lack of objective ideas about the real attitude of the teaching staff towards ongoing reforms significantly reduces the effectiveness of management processes in higher education [26-28].

\section{Materials and Methods}

At the preparatory stage of the study, to identify the subjective attitude of teachers towards changes in the higher education system, the authors did not want to offer teachers pre-allocated changes in the higher education system. The teachers were invited to identify the changes that affected their professional activities.

The survey involved teachers from both public and private universities in Nizhny Novgorod (NSPU named after K. Minin, Nizhny Novgorod Institute of Education Development, Moscow Humanitarian Institute (Nizhny Novgorod branch)). Factors such as age, gender, length of service at a university, academic degree, position, specialization were not taken into account at this stage of the study.

Based on the answers given by the teachers who participated in this study, the authors identified the following changes in higher education: introduction of competency-based approach, reduction of classroom time, technologization of the learning process, introduction of performance-based contracts for teachers, increase in the proportion of remote training.

With this in mind, the authors developed a "University teacher professional activity motivation study questionnaire".

To compile diagnostic tools, the teachers were asked to evaluate the impact of the changes described above in three aspects:

1) influence on the content and specifics of teachers' work,

2) impact on the quality of teachers' work (quality of students' training),

3) impact on teachers' professional development.

The assessment was carried out in the range from "-5" to "+5". Rating score of "-5" corresponded to the significant negative impact of the assessed change and rating score of "+5" corresponded to the significant positive impact. The results were calculated in average values.

The study involved 80 university teachers aged from 34 to 72 . Taking into account the fact that earlier studies, [5, $23,25]$ had obtained empirical data characterizing the dependence of the attitude of teachers to changes on age, qualifications and basic education; in this study, the participants were divided into two subgroups based on the duration of their work at university. The first group consisted of teachers with university work experience of 15 years or less (group I). These were the teachers whose professional activities at the university had started during the period of the active introduction of higher education reforms; they did not have experience in the old system of higher education. The second group included teachers with more than 15-year work experience in higher education (group II). The professional activities of these teachers had begun before Russia's accession to the Bologna Process and continued at the time of the study in the context of modernization processes. Moreover, all the teachers who took part in the study had at least 5-year work experience at higher education institution.

\section{Results}

The study of the subjective attitude of university teachers to the changes taking place in higher education in terms of their impact on the content and specifics of teachers' professional activities, on the quality of their work (i.e., on the quality of students' training) and their professional development, has been conducted. The results of the survey in average values are shown in Table 1. 
Table 1. University teachers' subjective perception of the significance of changes in education (in average, min $=-5 /$ significant negative impact, max $=+5 /$ significant positive impact)

\begin{tabular}{|c|c|c|}
\hline \multirow{3}{*}{ Direction of influence } & \multicolumn{2}{|c|}{ University work experience } \\
\hline & $\begin{array}{c}\text { Group I } \\
5 \text { to } 15 \text { years } \\
\end{array}$ & $\begin{array}{c}\text { Group II } \\
\text { more than } 15 \text { years } \\
\end{array}$ \\
\hline & \multicolumn{2}{|c|}{ introduction of competency-based approach } \\
\hline influence on the content and specifics of the teachers' work & +2.5 & +1.5 \\
\hline influence on the quality of the teachers' work & +1.1 & +0.2 \\
\hline \multirow[t]{2}{*}{ influence on the professional development } & +1.5 & +1.3 \\
\hline & \multicolumn{2}{|c|}{ reduction of classroom training time } \\
\hline influence on the content and specifics of the teachers' work & +0.2 & -1.5 \\
\hline influence on the quality of the teachers' work & -0.3 & -2.5 \\
\hline \multirow[t]{2}{*}{ influence on the professional development } & +1.8 & +1.6 \\
\hline & \multicolumn{2}{|c|}{ technologization of the learning process } \\
\hline influence on the content and specifics of the teachers' work & +2.1 & +1.9 \\
\hline influence on the quality of the teachers' work & -0.2 & -1.8 \\
\hline \multirow[t]{2}{*}{ influence on the professional development } & +2.2 & +1.8 \\
\hline & \multicolumn{2}{|c|}{ introduction of performance-based contracts for teachers } \\
\hline influence on the content and specifics of the teachers' work & +3.1 & +1.9 \\
\hline influence on the quality of the teachers' work & -0.3 & -0.7 \\
\hline \multirow[t]{2}{*}{ influence on the professional development } & -0.6 & -0.9 \\
\hline & \multicolumn{2}{|c|}{$\begin{array}{l}\text { increase in the proportion of remote training } \\
\text { (including full-time students) }\end{array}$} \\
\hline influence on the content and specifics of the teachers' work & +2.1 & +1.9 \\
\hline influence on the quality of the teachers' work & -0.2 & -1.5 \\
\hline influence on the professional development & +1.6 & +1.3 \\
\hline
\end{tabular}

\section{Discussion}

The data obtained allowed identifying several ambiguous and contradictory trends. Thus, it was found that most of the teachers participating in the survey, regardless of the length of service at the university, were relatively indifferent to changes in the system of higher education. In their opinion, these reforms were of small importance. The impact of most changes on the content and specifics of the teachers' work, on the quality of teachers' work (quality of student training), as well as on professional development, was assessed by the survey participants in the range from "-2" (minor negative changes) to "+2" (minor positive changes). This indicates that most of the changes, according to the subjective opinion of the teachers who took part in the study, did not have significant impact on the real situation of higher education.

Let us address the analysis of the teachers' subjective attitude to individual changes in higher education in more detail.

It seems optimistic that the introduction of competency-based approach to higher education was generally accepted by the pedagogical community and did not cause subjective denial and resistance. This was the only change, concerning which no negative values were revealed in any direction. Its influence on the content of teaching work, the quality of students' training and professional self-improvement were assessed in a positive range in both groups of teachers.

By comparison of these data with the previously published studies (for example, in the study by S.B. Seryakova and L.F. Krasinskaya [25], the overwhelming majority of teachers evaluated the introduction of FESs negatively), it is possible to judge about some positive dynamics in the change in the attitude of teachers to new goals in higher education.

Nevertheless, the impact of introducing the competency-based approach on the quality of students' training was estimated to be minimal $(+1.1$ and +0.2 in groups I and II, respectively).

The reduction of classroom time, technologization of the learning process, and increase in the proportion of remote training (including full-time students), in the opinion of the teachers who took part in the study, had a slight positive effect on the content and specifics of the teachers' work and their professional development. This can be explained by the fact that these changes allow teachers to acquire additional professional competencies. However, at the same time, all these changes, according to the teachers of both groups, negatively affected the quality of the teachers' 
professional activity, i.e. the quality of students' training. The maximum negative impact was identified for the change labeled as "Reduction of classroom time" $(-2.5$ in group II).

Of particular note is the assessment by teachers of such a change as "Introduction of performance-based contracts for teachers". The significance of this change was defined as "causing visible positive changes" concerning the content and specifics of the work of teachers (+3.1 in group I). This is the largest positive value recorded in the study. At the same time, the same change was rated by teachers of both groups as negative in terms of work productivity (quality of students' training) and professional self-improvement.

It requires special understanding that the teachers' work productivity, which was understood as the quality of students' training, in the opinion of the teachers of both groups participating in the study, was least of all dependent on the changes occurring in higher education and was mainly evaluated in the negative range. This causes some concern primarily because the quality of education is a priority area of modernization processes.

Compared the data obtained in groups of teachers with different university work experience, it can be concluded that teachers with experience of fewer than 15 years generally assess changes in the higher education system a little more optimistically, although the differences are not statistically significant. The absence of significant differences indirectly indicates that teachers with more experience of university work had already adapted to the changes that are taking place and evaluated their impact not based on the comparison with the previous experience, but based on the analysis of the real professional situation. Consequently, the ideas of modernization of education do not cause personal resistance among teachers.

\section{Conclusions}

The data obtained during the study allow formulating the following assumptions.

In general, the ideas of competency-based education, which have been accepted by the teaching staff of higher education institutions, are experienced as positive and do not cause subjective resistance. The impact of the introduction of competency-based approach on the content and specifics of the teachers' work, the quality of students' training and professional development is mainly assessed at the level of "insignificant positive impact".

The analysis of the attitude of teachers to other changes identified for the study has shown that most of the teachers who took part in the study were quite indifferent to the changes taking place in the higher education system. The impact of most changes on the content and specifics of the teachers' work, on the teachers' work quality (the quality of students' training) and professional development, was evaluated in the range from "minimal negative impact" to "minimal positive impact". Therefore, most of the changes, according to the subjective opinion of the teachers who took part in the survey, did not affect the qualitative change in the real situation in higher education.

The teachers, positively assessing the impact of the announced changes on professional activity and self-improvement, at the same time, believe that their impact is rather negative for the quality of students' training is quite interesting and requires additional reflection.

The comparison of the research data obtained in groups of teachers with different university work experience has not revealed significant differences, although teachers with less than 15-year work experience at the university assess the changes occurring in higher education a little more positively.

In conclusion, it should be emphasized that this study does not purport to be exhaustive. The data obtained, first of all, make it possible to outline a certain problem field for further research. For more objective understanding of the real situation, more detailed and thorough analysis of the obtained data and more detailed study of the subjective perception of the processes occurring in higher education by university teachers should be performed.

It seems that the solution to this problem is possible on an interdisciplinary basis, combining the approaches developed in psychology, sociology, administration and management. This may be the goal of a separate study.

\section{REFERENCES}

[1] O. Yu. Vasilenko, E. V. Velts. Prepodavatel vuza: motivatsiya i stimulirovanie trudovoi deyatelnosti (Obzor sotsiologicheskogo issledovaniya) [University lecturer: motivation and stimulation of work activities (Survey of sociological research)], Veni Vidi Vici, 1999. Online available from

http://www.vevivi.ru/best/Prepodavatel-vuza-motivatsiya-istimulirovanie-trudovoi-deyatelnosti-Obzor-sotsiologichesk ogo-issledovaniya-ref88191.html

[2] V. V. Serikov. Subektivnaya realnost pedagoga [The teacher's subjective reality], Pedagogika, Vol.10, 53-61, 2005.

[3] O. I. Vaganova, T. E. Lebedeva, M. P. Prokhorova, Z. V. Smirnova, A. A. Shkunova. Pedagogical support of the information-educational environment of the university [Article@Apoyo pedagógico del entornoinformativo-educa tivo de la universidad]. Espacios, Vol.40, No.2, 6, 2019.

[4] N. F. Avdeev. Vzglyad neravnodushnogo professora na problemy vysshei shkoly [A glance of a concerned professor on the problems of higher education], MGIU, Moscow, 2006.

[5] N. B. Moskvina. Izmeneniya v vysshem obrazovanii glazami prepodavatelei [Changes in higher education through the 
eyes of teachers], Pedagogicheskoe obrazovanie i nauka, Vol.6, 55-60, 2012.

[6] E. G. Gutsu, M. D. Nyagolova, T. A. Runova. Issledovanie motivatsii trudovoi deyatelnosti prepodavatelya vuza [Study of the motivation of the university teacher at work], Vestnik Mininskogo universiteta, Vol.6, No.3(24), 13, 2018.

[7] E. G. Gutsu, N. N. Demeneva, E. V. Kochetova, T. V. Mayasova, N. V. Belinova. Studying motivational-axiological component of professional competence of a college teacher, International Journal of Environmental and Science Education, Vol.11, No.18, 12650-12657, 2016.

[8] S. N. Sorokoumova, E. G. Gutsu. Razvitie motivatsionno-tsennostnogo komponenta professionalnoi kompetentsii prepodavatelya vuza $\mathrm{v}$ sisteme vnutrivuzovskogo povysheniya kvalifikatsii [The development of the motivational and value-based component of the professional competence of a university teacher in the system of intra-university continuing education], Privolzhskii nauchnyi zhurnal, Vol.4 305-309, 2014.

[9] A. A. Fedorov, G. A. Paputkova, E. K. Samerkhanova, I. F. Filchenkova. New Design of University Educational Ecosystem in the Context of Modernisation of Teacher Education in Russia. Psikhologicheskaya nauka i obrazovanie-psychological science and education, Vol.23, No.1, 52-63, 2018.

[10] E. Y. Ilaltdinova, S. V. Frolova, I. V. Lebedeva. Top qualities of great teachers: National and universal, Advances in Intelligent Systems and Computing, Vol.677, 44-52, 2018.

[11] M. J. Salihu. Demographic Change and Transition in Southeast Asia: Implications for Higher Education, Universal Journal of Educational Research, Vol.8, No.2, 678-688, 2020.

[12] S. Hidi, J. M. Harackiewicz. Motivating the corporatelly unmotivated: A critical issue for the 21st century, Review of Educational Research, Vol.70, No.2, 151-179, 2013.

[13] S. Nicolai (ed.). Opportunities for change. Education innovation and reform during and after conflict. Internation Institute for Education Planning. UNESCO, 2009. Online available from http://unesdoc.unesco.org/images/0018/0018 38/183808e.pdf

[14] T. A. Zhalagina. Motivatsionnyi aspekt profilaktiki professionalnoi deformatsii lichnosti prepodavatelya vuza [The motivational aspect of the prevention of professional deformation of the personality of a university teacher], Chelovecheskii faktor: problemy psikhologii i ergonomiki, Vol.2, 11-14, 2006.

[15] N. O. Sadovnikova, A. M. Mirzaakhmedov. Aktualnye smyslovye sostoyaniya pedagogov, perezhivayushchikh professionalnyi krizis lichnosti [Current semantic states of teachers experiencing a professional personality crisis], Obrazovanie i nauka, Vol.21, No.2, 113-131, 2019.

[16] E. F. Zeer, E. T. Konyukhova. Psikhologicheskie faktory vliyaniya ustanovki pedagogov na innovatsionnuyu deyatelnost [Psychological factors of the influence of the attitude of teachers on innovation], Obrazovanie i nauka,
Vol.4, 41-49, 2010.

[17] O. V. Manyakhina. Motivatsiya tvorcheskoi deyatelnosti v pedagogicheskom kollektive [Motivation of creative activity in the teaching staff], Molodoi uchenyi, Vol.1, 733-735, 2016.

[18] E. V. Myalkina, E. V. Zhitkova. Sistema kompleksnoi otsenki administrativno-upravlencheskogo personala v vuze: praktika i osobennosti [The system of integrated assessment of administrative and managerial personnel at the university: practice and features]. Vestnik Mininskogo universiteta, Vol.6, No.1, 2, 2018.

[19] I. G. Sevastyanova, V. N. Stegnii, A. G. Sposib. Motivatsiya innovatsionnoi proektnoi komandy [Motivation of an innovative project team]. Innovatsii, Vol.12, No.146, 95-99, 2010.

[20] I. F. Filchenkova. Rezultaty monitoringa innovatsionnoi aktivnosti prepodavatelei vuza [Results of innovative activity monitoring in university teachers], Vestnik Mininskogo universiteta, Vol.3, 4, 2017.

[21] L. Armstrong. Barriers to Innovation and Change in Higher Education. TIAA-CREF Institute, 2014. Retrieved from: https://pdfs.semanticscholar.org/d513/141cb6af397d22a68d 99fa9264875f888312.pdf

[22] Yu. V. Senko, M. N. Frolovskaya. Evolyutsiya professionalnogo obraza mira pedagoga [The evolution of the professional image of the teacher's world], Pedagogika, Vol.2, 50-55, 2009.

[23] M. V. Polevaya. Sovremennyi prepodavatel: vzglyad na studentov i metodiki prepodavaniya v vuze [Modern teacher: a glance at students and teaching methods at the university], Gumanitarnye nauki. Vestnik Finansovogo universiteta, Vol.3, No.19, 83-90, 2015.

[24] P. A. Ambarova, G. E. Zborovskii, N. V. Shabrova. "Staroe” i "novoe" doverie v vysshem obrazovanii ["Old" and "new" trust in higher education], Obrazovanie i nauka, Vol.21, No.1, 9-36, 2019. https://doi.org/10.17853/1994-56 39-2019-1-9-36

[25] S. B. Seryakova, L. F. Krasinskaya. Reforma vysshego obrazovaniya glazami prepodavatelei: rezultaty issledovaniya [Reform of higher education through the eyes of teachers: research results], Vysshee obrazovanie v Rossii, Vol.4, 22-29, 2013.

[26] V. V. Volchik, Yu. V. Filonenko, E. S. Averkieva, I. M. Shiryaev. Byurokratizatsiya i adaptivnoe povedenie v sfere vysshego obrazovaniya [Bureaucratization and adaptive behavior in higher education], Voprosy regulirovaniya ekonomiki, Vol.7, No.4, 57-71, 2016.

[27] E. G. Gutsu, Yu. Yu. Chilipenok. Model vnutrikafedralnogo upravleniya motivatsiei prepodavatelei vuza [The model of intra-department management of university teachers' motivation], Vysshee obrazovanie v Rossii, Vol.12, 69-78, 2018.

[28] K. S. Drezinskii. Sovershenstvovanie sistemy upravleniya personalom vysshikh uchebnykh zavedenii [Improving the personnel management system of higher educational institutions], Izvestiya Sankt-Peterburgskogo universiteta ekonomiki i finansov, Vol.3, No.51, 169-172, 2007. 